\title{
Štruktúra a sezónna dynamika spoločenstva vtákov v chránenom areáli Levické rybníky v rokoch 2018 - 2020
}

\author{
Structure and seasonal dynamics of bird assemblage \\ in the Levice fishponds protected area in 2018-2020
}

\section{Terézia Jauschová \& Peter $\mathbf{Z}_{\text {ACH }}$}

Ústav ekológie lesa SAV, L. Štúra 2, 96053 Zvolen, Slovensko; e-mail: tereziajauschova@ife.sk, zach@ife.sk

\begin{abstract}
The bird assemblages in the Levice fishponds protected area, SW Slovakia, has been analyzed. Altogether 156 bird species, of them 83 (53\%) water birds (living on or around water) were found in 2018-2020. Breeding was recorded in 20 species of water birds, of which Fulica atra, Anas plathyrhynchos and Podiceps cristatus were predominant. The number of water bird species was highest in the spring (66) and lowest during the winter (18). The following species were first recorded there between 2018 and 2020: Ardeola ralloides, Hydroprogne caspia, Lymnocryptes minimus, Tringa erythropus, Podiceps auritus, Cygnus cygnus, Tadorna tadorna, Grus grus and Aquila chrysaetos. Our results supported the great importance of the Levice fishponds as a habitat of many bird species over the year, reflecting extensive management of man-made fishponds.
\end{abstract}

Key words: water birds, faunistics, nature conservation, fishponds, Slovakia

\section{Úvod}

Mnohé prirodzené mokradné biotopy na Slovensku činnost'ou človeka zanikli alebo sú v súčasnosti kriticky ohrozené. Rybníky vybudované človekom dnes do značnej miery nahrádzajú zaniknuté mokrade. Príkladom náhradného mokradného biotopu na juhozápadnom Slovensku je antropogénna lokalita Levické rybníky. Pôvodne išlo o ryžoviská z povojnového obdobia, ktoré boli v rokoch 1950 - 1956 z ekonomických dôvodov prebudované na rybníky (Drahoš 1968). Lokalita poskytuje útočisko najmä vodným vtákom, obojživelníkom, vodným bezstavovcom a d'alším na vodné prostredie viazaným organizmom.

Prvé údaje o výskyte vtáctva na Levických rybníkoch poskytujú práce $\mathrm{A}$. Randíka (Randík
1962) a M. Drahoša (Drahoš 1968). S odstupom času boli zverejnené výsledky výskumu vtáčích spoločenstiev na Levických rybníkoch (Zach 1985, 1987, 1988a,b, 1990, 1999, 2002). Následný výskum v rokoch 2003 - 2005 umožnil porovnat' výskyt vtáctva na lokalite za uplynulých približne 50 rokov (Turčoková 2006). Výskum a monitoring vtáctva tu prebieha aj v súčasnosti (Jauschová et al. 2019).

Väčšina publikovaných prác o vtáctve Levických rybníkov je venovaná vodným a na vodné prostredie viazaným druhom vtákov. Ciel'om tejto práce je poskytnút' ucelené informácie o ornitocenóze Levických rybníkov s osobitným zretel'om na obdobie 2018 - 2020 a aktualizovat' ekosozologický význam predmetnej lokality z hl'adiska výskytu vtáctva. 


\section{Charakteristika územia}

Levické rybníky (JZ Slovensko, GPS N 48¹1.59597`, E $18^{\circ} 36.70305^{\circ}$ ) ležia na okraji intravilánu mesta Levice (DFS 7877). Za chránené územie (CHŠP) boli vyhlásené v roku 1974 za účelom ochrany vodného vtáctva a vodných biocenóz. Výmera súčasného chráneného územia (Chránený areál Levické rybníky) je 91,83 ha a platí v ňom 3 . stupeň ochrany prírody (http://uzemia.enviroportal.sk/main/detail/ cislo/89). Rybničnú sústavu tvorí šest’ plytkých rybníkov (rybník I až VI v smere od mesta Levice, obr. 1), ktoré sú v rôznej miere porastené makrofytnou vegetáciou, predovšetkým Phragmites australis. V litorálnych porastoch sú d'alej hojne zastúpené Typha latifolia a Typha angustifolia. Na hrádzach rybníkov rastú kry ako napríklad Prunus spinosa, Sambucus nigra, Rosa canina, Swida sanguinea. Na západe rybničnú sústavu obteká kanál Teler a na východe potok Perec. Brehové porasty potoka Perec tvoria prevažne Alnus glutinosa, Salix spp. a Fraxinus excelsior s hustým podrastom krov. V bezprostrednom okolí rybníkov sa na západe nachádza priemyselná zóna, na východe a juhu agrárna krajina a na severe sídlisko Rybníky III.

Hospodárske chovné rybníky bez možnosti športového rybolovu sú zamerané predovšetkým na chov kapra, št’uky a v menšej miere sumca. V závislosti od rybárskeho obhospodarovania sa na jednotlivých rybníkoch sezónne mení stav vodnej hladiny. Rybníky sú plne napustené vo vegetačnom období a každoročne na jeseň sa pri výlove rýb vypúšstajú. Vypustené rybníky na jeseň, $v$ zime a skoro na jar charakterizuje súvislé bahnité dno a suché porasty tvrdých makrofytov. V zime 2019/2020 ostali tri menšie rybníky (rybník IV, V, VI) napustené. Na jar v roku 2020 sa väčšie rybníky (rybník I, II, III) začali napúšt’at’ až začiatkom mája, teda podstatne neskôr ako $\mathrm{v}$ iných rokoch.

\section{Metodika}

Výskyt vtáctva na Levických rybníkoch sme zaznamenávali počas 85 kontrol v období od 20.7.2018 do 15.10.2020. Kontroly sme vykonávali v rôznych denných hodinách, najmä do-

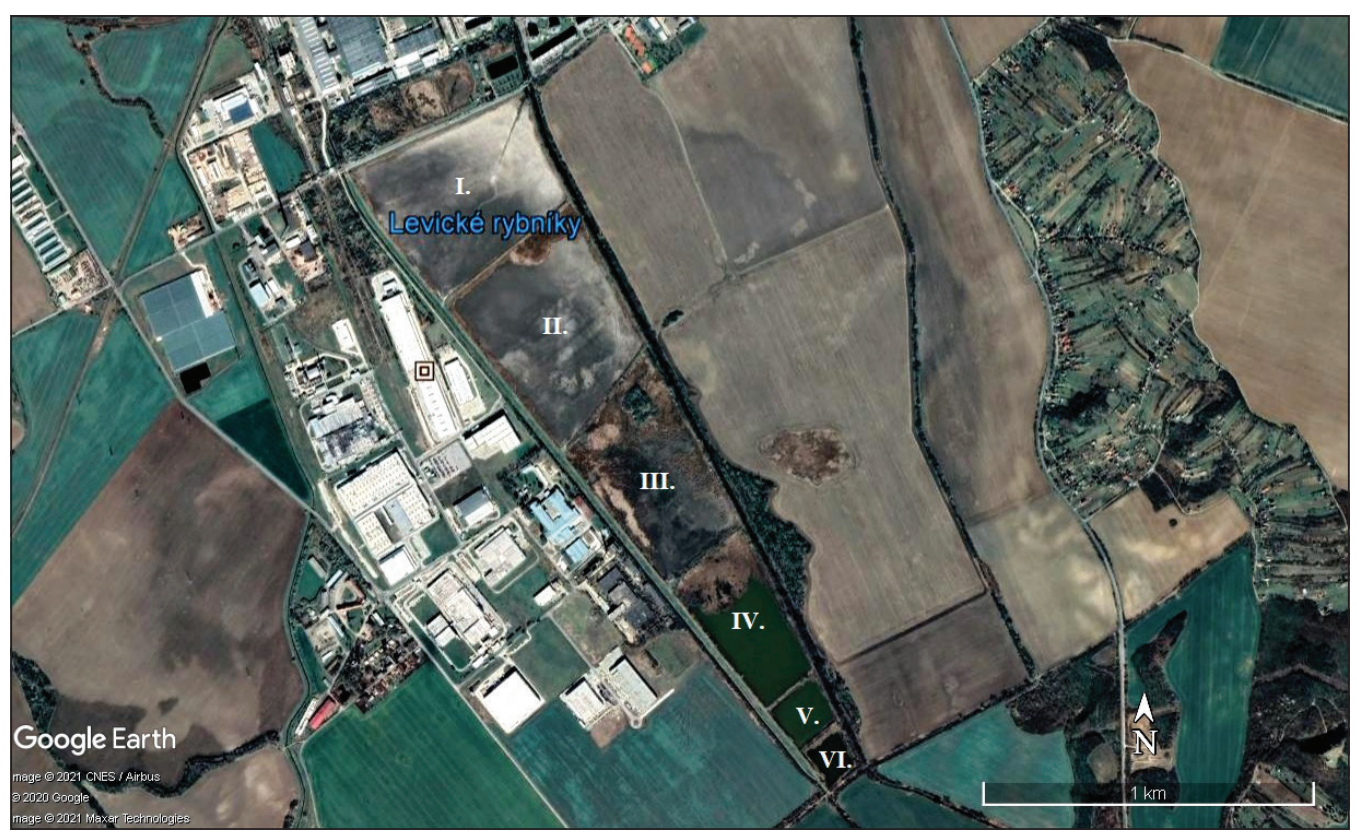

Obr. 1. Chránený areál Levické rybníky a okolitá krajina (Google Earth 2021).

Fig. 1. The protected area Levice fishponds and surrounding landscape (Google Earth 2021). 
poludnia, v priemere raz týždenne, $v$ hniezdnom a migračnom období aj častejšie. $\mathrm{V}$ zimných mesiacoch (december - február) bola frekvencia kontrol nižšia ( $1-3$ kontroly mesačne). V roku 2020 boli kontroly hlavne začiatkom hniezdneho obdobia vykonávané menej často (spolu 20 návštev v uvedenom roku). Celkove sme v jarnom a letnom období (marec - august) vykonali spolu 40 návštev a v jesennom a zimnom období (september - február) spolu 45 kontrol. Vtáky sme zaznamenávali z hrádzí rybníkov vizuálne a akusticky. Boli zaznamenávané údaje naznačujúce hniezdenie konkrétneho druhu (napr. tok, párenie, stavba hniezda, nález hniezda, zanášanie potravy, kŕmenie mlád'at, samica s mlád'atami). Zaznamenávali sme všetky druhy vtákov, no s osobitným zretel'om na druhy viazané na vodu, vodné a močiarne biotopy.

$Z$ dát získaných v teréne sme vypočítali frekvenciu výskytu a relatívnu početnost' vodných druhov vtákov v spoločenstve za celé sledované obdobie a v jednotlivých ročných obdobiach (Janda \& Řepa 1986). Vyhodnotili sme sezónnu dynamiku počtu druhov vodných vtákov na lokalite (S) a sezónnu dynamiku počtu jedincov u dominantných vodných druhov Fulica atra a Anas platyrhynchos. (N). Jednotlivé druhy vtákov boli podl'a charakteru výskytu kategorizované ako hniezdiace (dokázané, pravdepodobné, možné hniezdenie), transmigranty alebo hospites. Za dokázané hniezdenie boli považované pozorovania druhov v kategórii D10 - D16, za pravdepodobné hniezdenie pozorovania v kategórii C3 - C9 a za možné hniezdenie pozorovania $\mathrm{v}$ kategórii B1 - B2 (Medzinárodná stupnica preukaznosti hniezdenia).

Názvoslovie vtákov v tejto práci uvádzame podl'a Kovalika et al. (2010). Medzi vodné a pri vode žijúce vtáky sme zaradili druhy podl'a práce Danka (2006).

\section{Výsledky}

$\mathrm{Na}$ Levických rybníkoch sme v období 20. 7. 2018 - 15. 10. 2020 zistili výskyt spolu 156 druhov vtákov. Z toho 83 druhov (53\% všetkých zistených druhov) bolo vodných alebo pri vode žijúcich. Spolu 9 druhov vtákov sme na lokalite zaznamenali prvýkrát, konkrétne: Ardeola ralloides, Hydroprogne caspia, Lymnocryptes minimus, Tringa erythropus, Podiceps auritus, Cygnus cygnus, Tadorna tadorna, Grus grus a Aquila chrysaetos.

Počet druhov vtákov v kategóriách hniezdiče, transmigranty a hospites znázorňuje obrázok 2 . V skupine vodných a na vodu viazaných druhov vtákov sme hniezdenie preukázali u 20 druhov a u 7 druhov sme zistili pravdepodobné alebo možné hniezdenie (obr. 2). Počas jednej návštevy sme najviac zistili 57 druhov (26.5 2019) a najmenej 14 druhov (24.11. 2019).

V spoločenstve vodných druhov vtákov na Levických rybníkoch počas celého roka okrem zimy dominuje lyska čierna Fulica atra. Dominantne sa uplatňujú aj viaceré druhy kačíc, najmä Anas plathyrhynchos, predovšetkým v období migrácie. Najvyššiu abundanciu týchto dvoch druhov možno pozorovat' koncom hniezdneho obdobia, kedy sa na lokalite vyskytujú vyhniezdené vtáky s mlád’atami, ako aj migrujúce jedince (obr. 3). Z hl'adiska frekvencie výskytu konštantné druhy, zaznamenané na lokalite sú: Ardea cinerea, Anas plathyrhynchos, Ardea alba, Cygnus olor, Fulica atra, Podiceps cristatus, Aythya ferina a Tachybaptus ruficollis.

Počet druhov vtákov na Levických rybníkoch sa v rámci roka značne mení (obr. 4). Prvá kulminácia počtu druhov je charakteristická pre jarnú migráciu a druhá kulminácia pre jesennú migráciu. Sezónnu dynamiku vodných druhov vtákov špecificky ovplyvňuje vypúšt'anie rybníkov na jeseň a ich napúšt'anie na jar, prípadne aj zamŕzanie vodnej hladiny v zime.

Prehl'ad vodných a na vodu viazaných druhov vtákov v Chránenom areáli Levické rybníky v období 20.7.2018 - 15.10.2020 s charakteristikami výskytu poskytuje tabul'ka 1 .

V jarnom období (marec - máj) sa na lokalite vyskytuje najviac druhov vodných a na vodu viazaných vtákov. Toto obdobie charakterizuje napúšt'anie rybníkov, kedy vznikajú vhodné podmienky pre výskyt bahniakov (Charadriiformes) a zástupcov zúbko- 


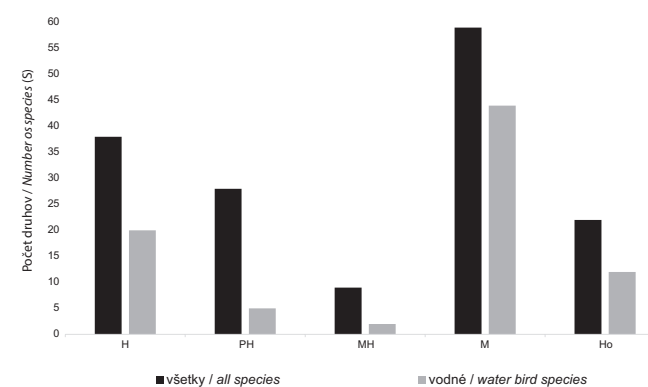

Obr. 2. Počet druhov vtákov (S) zaznamenaných v Chránenom areáli Levické rybníky 20. 7. 2018 -15. 10. 2020. Hniezdiace druhy $(\mathrm{H}$ - dokázané hniezdenie, $\mathrm{PH}$ - pravdepodobné hniezdenie, MH - možné hniezdenie), M - transmigranty, Ho - hospites.

Fig. 2. Number of bird species (S) recorded in the Levice fishponds between July 20th 2018 - October 15th 2020. Breeding species $(\mathrm{H}$ - recorded breeding, $\mathrm{PH}-$ probable breeding, $\mathrm{MH}$ - possible breeding), M-migrants Ho-hospites.

zobcov (Anseriformes). Zistili sme v ňom až 66 vodných a na vodné prostredie viazaných druhov s dominanciou Fulica atra (33,6 \%), Anas plathyrhynchos (11,2\%), Aythya ferina $(6,2 \%)$, Podiceps cristatus $(6,1 \%)$ a Cygnus olor $(5,5 \%)$. K najzaujímavejším $\mathrm{z}$ tohto obdobia patria pozorovania druhov Plegadis falcinellus, Hydroprogne caspia, Ardeola ralloides, Ichthyaetus melanocephalus, Grus grus, Porzana porzana, Porzana parva, Charadrius hiaticula a Lymnocryptes minimus.

Letné obdobie (jún - august) charakterizuje plný vodný stav rybníkov. Zistili sme v ňom výskyt 49 vodných a na vodu viazaných druhov s dominanciou druhov Fulica atra (47,3\%), Anas plathyrhynchos (23,1\%), Podiceps cristatus (6,6\%), Cygnus olor (5,0 \%) a Aythya ferina

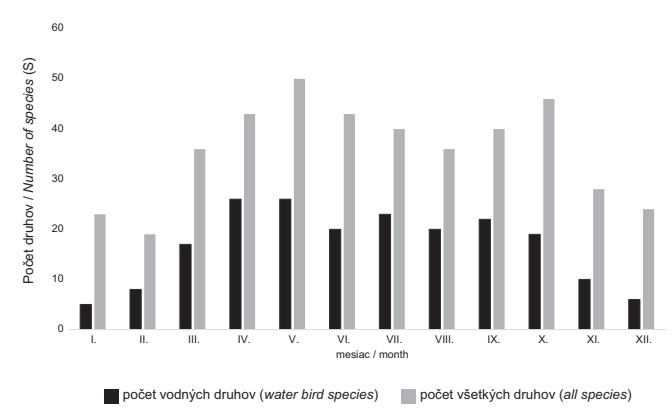

Obr. 4. Sezónne zmeny v počte druhov vtákov (S) v Chránenom areáli Levické rybníky v období 20. 7. 2018-15.10. 2020. Fig. 4. Seasonal changes in the number of bird species (S) in the Protected Area Levice fishponds between July 20th 2018 - October 15th 2020.

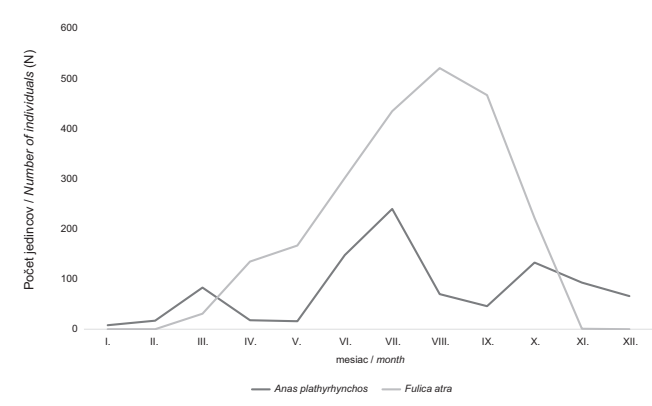

Obr. 3. Sezónne zmeny v počte jedincov $(N)$ dominantných vodných druhov Fulica atra a Anas platyrhynchos v Chránenom areáli Levické rybníky v roku 2019.

Fig. 3. Seasonal changes in the number $(N)$ of predominant water bird species Fulica atra and Anas platyrhynchos in the Protected Area Levice fishponds in 2019.

(4,0 \%). Faunisticky pozoruhodné z tohto obdobia sú pozorovania Podiceps auritus, Podiceps nigricollis, Microcarbo pygmaeus a pravidelný výskyt druhov Porzana parva, Ardea purpurea a Aythya nyroca.

V jesennom období (september - november) dochádza opät' $\mathrm{k}$ významnej zmene charakteru rybníkov počas vypúšt’ania vody a pri výlove rýb. Charakteristický je výskyt viacerých druhov kačíc, čajok, bahniakov, ale aj početných zoskupení ichtyofágnych druhov Phalacrocorax carbo, Ardea cinerea a Ardea alba. V tomto období sme zaznamenali výskyt 54 vodných a pri vode žijúcich druhov vtákov s dominantným zastúpením druhov Fulica atra (32,8 \%), Anas plathyrhynchos (17,7\%), Ardea cinerea (7,5\%), Ardea alba (6,8\%) a Cygnus olor $(6,8 \%)$. Zaujímavé sú pozorovania druhov Aix sponsa, Botaurus stellaris, Pluvialis squatarola, Cygnus cygnus, Mergellus albellus a Panurus biarmicus.

Zimné obdobie (december - február) sa na lokalite vyznačuje najnižším počtom druhov v spoločenstve vodných vtákov na vypustených alebo zamrznutých rybníkoch. Celkovo sme v ňom zistili výskyt 18 druhov vodných vtákov s dominanciou druhov Anas plathyrhynchos (58,3\%), Ardea cinerea (12,7\%), Ardea alba (7,1 \%), Emberiza schoeniclus (5,6\%) a Anser anser (3,6\%). Rozsiahle porasty litorálnej vegetácie predstavujú vhodný biotop pre zimovanie Rallus aquaticus, Panurus biarmicus a Emberiza schoeniclus. 
Tab. 1. Prehl'ad a charakteristika vodných a na vodu viazaných druhov vtákov v Chránenom areáli Levické rybníky (20. 7. 2018 - 15. 10. 2020).

Table 1. Survey and characteristics of bird species living on or around water in the Protected area Levice fishponds (July 20th 2018 - October 15th 2020).

$\mathrm{MP}=$ maximálny počet jedincov, $\mathrm{CHV}$ - charakter výskytu, $\mathrm{KH}$ - kategória hniezdenia $(\mathrm{H}-$ hniezdič, $\mathrm{PH}-$ pravdepodobný hniezdič, MH - možný hniezdič, M - transmigrant, Ho - hospites), IUCN SK = stupeň ohrozenia, F - frekvencia, D \% - dominancia abundancie, D \% jar - dominancia na jar, D \% leto - dominancia v lete, D \% jeseň - dominancia v jeseni, D \% zima - dominancia $v$ zime, hrubým písmom -5 druhov s najvyššou dominanciou.

$M P=$ maximum number of individuals, $\mathrm{CHV}$ - character of occurence, $\mathrm{KH}$ - breeding category $(\mathrm{H}-$ breeding species, $\mathrm{PH}-$ probably breeding species, $\mathrm{MH}$ - possibly breeding species, $\mathrm{M}$ - migrant, Ho - hospites), IUCN SK - conservation status according to Slovak Red List, F-frequency, D \% -dominance of abundance, D \% jar-dominance in spring, D \% leto-dominance in summer, $D \%$ jeseň - dominance in autumn, D \% zima - dominance in winter, species marked in bold - the five predominant species.

\begin{tabular}{|c|c|c|c|c|c|c|c|c|c|c|}
\hline Druh / Species & MP & $\mathrm{CHV}$ & $\mathrm{KH}$ & $\begin{array}{c}\text { IUCN } \\
\text { SK }\end{array}$ & $\mathrm{F}$ & D \% & $\begin{array}{l}\text { D \% } \\
\text { jar }\end{array}$ & $\begin{array}{l}\mathrm{D} \% \\
\text { leto }\end{array}$ & $\begin{array}{l}\mathrm{D} \% \\
\text { jeseň }\end{array}$ & $\begin{array}{l}\mathrm{D} \% \\
\text { zima }\end{array}$ \\
\hline Anser anser & 14 & $\mathrm{H}$ & D12 & $\mathrm{LC}$ & 25,9 & 0,3 & 1,8 & $<0,1$ & & 3,6 \\
\hline Anser albifrons & 11 & M & & & 8,2 & $<0,1$ & & & 0,2 & 1,5 \\
\hline Cygnus olor & 79 & $\mathrm{H}$ & D13 & LC & 82,4 & 5,7 & 5,5 & 5 & 6,8 & 0,7 \\
\hline Cygnus cygnus & 1 & M & & & 1,2 & $<0,1$ & & & $<0,1$ & \\
\hline Tadorna tadorna & 1 & M & & & 2,4 & $<0,1$ & & & $<0,1$ & \\
\hline Anas strepera & 17 & M & & LC & 29,4 & 0,4 & 0,2 & 0,2 & 0,6 & \\
\hline Anas penelope & 24 & M & & & 17,7 & 0,2 & 0,1 & $<0,1$ & 0,5 & \\
\hline Anas platyrhynchos & 960 & $\mathrm{H}$ & D12 & LC & 95,3 & 20 & 11,2 & 23,1 & 17,7 & 58,3 \\
\hline Anas clypeata & 23 & M & & VU & 35,3 & 0,5 & 1 & 0,2 & 0,7 & 1,3 \\
\hline Anas acuta & 7 & M & & CR & 17,7 & 0,1 & & & 0,3 & \\
\hline Anas querquedula & 32 & M & & NT & 16,5 & 0,3 & 1,3 & 0,3 & $<0,1$ & \\
\hline Anas crecca & 160 & M & & EN & 28,2 & 1,8 & 0,5 & 1 & 3,2 & \\
\hline Netta rufina & 17 & $\mathrm{H}$ & D12 & LC & 45,9 & 0,5 & 0,9 & 0,6 & 0,3 & \\
\hline Aythya ferina & 105 & $\mathrm{H}$ & D12 & LC & 78,8 & 3,8 & 6,2 & 4 & 3 & 0,7 \\
\hline Aythya nyroca & 4 & $\mathrm{MH}$ & & EN & 22,4 & 0,1 & 0,2 & $<0,1$ & $<0,1$ & \\
\hline Aythya fuligula & 12 & $\mathrm{PH}$ & C3 & LC & 47,1 & 0,4 & 1 & 0,2 & 0,5 & 0,3 \\
\hline Bucephala clangula & 2 & M & & & 2,4 & $<0,1$ & $<0,1$ & & $<0,1$ & \\
\hline Mergellus albellus & 1 & M & & & 1,2 & $<0,1$ & & & $<0,1$ & \\
\hline Mergus merganser & 2 & M & & & 1,2 & $<0,1$ & & & $<0,1$ & \\
\hline Tachybaptus ruficollis & 139 & $\mathrm{H}$ & D12 & LC & 77,7 & 3,6 & 3,1 & 3,5 & 4 & \\
\hline Podiceps cristatus & 123 & $\mathrm{H}$ & D15 & LC & 80 & 6 & 6,1 & 6,6 & 5,4 & \\
\hline Podiceps auritus & 1 & M & & & 1,2 & $<0,1$ & & $<0,1$ & & \\
\hline Podiceps nigricollis & 1 & M & & EN & 1,2 & $<0,1$ & $<0,1$ & & & \\
\hline Ciconia nigra & 2 & Ho & & LC & 9,4 & $<0,1$ & $<0,1$ & $<0,1$ & & \\
\hline Ciconia ciconia & 5 & Ho & & LC & 7,1 & $<0,1$ & $<0,1$ & $<0,1$ & & \\
\hline Microcarbo pygmaeus & 1 & Ho & & & 2,4 & $<0,1$ & $<0,1$ & $<0,1$ & & \\
\hline Phalacrocorax carbo & 74 & Ho & & VU & 71,8 & 2 & 0,6 & 0,8 & 3,8 & 3,3 \\
\hline Plegadis falcinellus & 1 & M & & & - & - & - & & & \\
\hline Botaurus stellaris & 1 & M & & VU & 1,2 & $<0,1$ & & & $<0,1$ & \\
\hline Ixobrychus minutus & 8 & $\mathrm{H}$ & D12 & LC & 18,8 & $<0,1$ & $<0,1$ & 0,2 & $<0,1$ & \\
\hline Nycticorax nycticorax & 4 & Ho & & LC & 14,1 & $<0,1$ & 0,4 & $<0,1$ & & \\
\hline Ardeola ralloides & 1 & M & & & 1,2 & $<0,1$ & $<0,1$ & & & \\
\hline Ardea cinerea & 90 & Ho & & LC & 100 & 4,1 & 3,7 & 1 & 7,5 & 12,7 \\
\hline Ardea purpurea & 3 & $\mathrm{MH}$ & B1 & VU & 17,7 & $<0,1$ & 0,1 & $<0,1$ & $<0,1$ & \\
\hline Ardea alba & 147 & Ho & & VU & 92,9 & 3,7 & 1,1 & 1,6 & 6,8 & 7,1 \\
\hline Egretta garzetta & 3 & Ho & & VU & 4,7 & $<0,1$ & & $<0,1$ & & \\
\hline Pandion haliaetus & 1 & M & & & - & - & & & - & \\
\hline Haliaeetus albicilla & 1 & Ho & & VU & 5,9 & $<0,1$ & $<0,1$ & $<0,1$ & $<0,1$ & \\
\hline Circus aeruginosus & 20 & $\mathrm{H}$ & D15 & LC & 58,8 & 0,9 & 2,5 & 1,1 & 0,3 & \\
\hline Grus grus & 2 & M & & & & - & - & - & & \\
\hline Rallus aquaticus & 3 & $\mathrm{H}$ & D12 & LC & 48,2 & 0,1 & 0,2 & $<0,1$ & 0,2 & 0,4 \\
\hline Porzana parva & 1 & $\mathrm{H}$ & D12 & VU & 3,5 & $<0,1$ & $<0,1$ & $<0,1$ & & \\
\hline Porzana porzana & 1 & M & & NT & 1,2 & $<0,1$ & $<0,1$ & & & \\
\hline Gallinula chloropus & 10 & $\mathrm{H}$ & D12 & LC & 50,6 & 0,3 & $<0,1$ & 0,3 & 0,3 & \\
\hline Fulica atra & 796 & $\mathrm{H}$ & D12 & LC & 81,2 & 39 & 33,6 & 47,3 & 32,8 & 0,7 \\
\hline Vanellus vanellus & 120 & M & & VU & 30,6 & 0,9 & 5,1 & $<0,1$ & 0,5 & \\
\hline Pluvialis squatarola & 2 & M & & & 9,4 & $<0,1$ & & & $<0,1$ & \\
\hline Charadrius hiaticula & 8 & M & & & 1,2 & $<0,1$ & 0,2 & & 0 & \\
\hline Charadrius dubius & 3 & M & & LC & 3,5 & $<0,1$ & 0,1 & & & \\
\hline Lymnocryptes minimus & 1 & M & & & - & - & - & & & \\
\hline Gallinago gallinago & 12 & M & & EN & 15,3 & $<0,1$ & 0,4 & 0 & $<0,1$ & \\
\hline Tringa nebularia & 11 & M & & & 10,6 & $<0,1$ & 0,4 & & $<0,1$ & \\
\hline Tringa ochropus & 3 & M & & & 9,4 & $<0,1$ & 0,1 & & $<0,1$ & \\
\hline Tringa erythropus & 8 & M & & & - & - & - & & & \\
\hline Tringa glareola & 20 & M & & & 4,7 & $<0,1$ & 0,5 & $<0,1$ & & \\
\hline Tringa totanus & 2 & M & & EN & - & - & - & & & \\
\hline Actitis hypoleucos & 5 & $\mathrm{M}$ & & LC & 21,2 & $<0,1$ & $<0,1$ & $<0,1$ & $<0,1$ & \\
\hline
\end{tabular}




\begin{tabular}{|c|c|c|c|c|c|c|c|c|c|c|}
\hline Druh / Species & MP & CHV & $\mathrm{KH}$ & $\begin{array}{c}\text { IUCN } \\
\text { SK }\end{array}$ & $\mathrm{F}$ & D \% & $\begin{array}{l}\text { D \% } \\
\text { jar }\end{array}$ & $\begin{array}{l}\mathrm{D} \% \\
\text { leto }\end{array}$ & $\begin{array}{c}\text { D \% } \\
\text { jeseň }\end{array}$ & $\begin{array}{l}\text { D \% } \\
\text { zima }\end{array}$ \\
\hline Calidris alpina & 66 & $\bar{M}$ & & & 16,5 & 0,6 & 0,6 & & 1,3 & \\
\hline Philomachus pugnax & 7 & M & & & 7,1 & $<0,1$ & $<0,1$ & & 0,1 & \\
\hline Chroicocephalus ridibundus & 80 & M & & LC & 50,6 & 0,9 & 1,3 & 0,6 & 1,2 & \\
\hline Ichthyaetus melanocephalus & 1 & M & & NT & - & - & - & & & \\
\hline Larus canus & 5 & M & & & 4,7 & $<0,1$ & 0,1 & 0 & $<0,1$ & \\
\hline Larus cachinnans & 13 & M & & LC & 17,7 & 0,1 & 0,2 & $<0,1$ & 0,2 & 0,1 \\
\hline Hydroprogne caspia & 1 & M & & & 1,2 & $<0,1$ & $<0,1$ & & & \\
\hline Sterna hirundo & 1 & M & & LC & - & - & & - & & \\
\hline Chlidonias hybrida & 10 & M & & VU & 3,5 & $<0,1$ & 0,2 & $<0,1$ & & \\
\hline Chlidonias niger & 5 & M & & EN & 4,7 & $<0,1$ & 0,1 & $<0,1$ & & \\
\hline Alcedo atthis & 7 & $\mathrm{H}$ & D14 & LC & 62,4 & 0,3 & 0,2 & 0,1 & 0,4 & 2 \\
\hline Remiz pendulinus & 7 & $\mathrm{H}$ & D12 & LC & 12,9 & $<0,1$ & 0,1 & $<0,1$ & 0,1 & 0,3 \\
\hline Panurus biarmicus & 13 & $\mathrm{PH}$ & C4 & NT & 8,2 & $<0,1$ & 0,1 & & 0,1 & 0,9 \\
\hline Riparia riparia & 2 & Ho & & NT & - & - & & & & \\
\hline Acrocephalus arundinaceus & 40 & $\mathrm{H}$ & D16 & LC & 36,5 & 0,9 & 3,4 & 1 & $<0,1$ & \\
\hline Acrocephalus schoenobaenus & 10 & $\mathrm{H}$ & C4 & LC & 16,5 & $<0,1$ & 0,3 & $<0,1$ & $<0,1$ & \\
\hline Acrocephalus scirpaceus & 12 & $\mathrm{H}$ & D12 & LC & 29,4 & 0,2 & 1,4 & 0,1 & & \\
\hline Acrocephalus palustris & 8 & $\mathrm{PH}$ & C4 & LC & 15,3 & $<0,1$ & 0,3 & $<0,1$ & & \\
\hline Locustella naevia & 1 & M & & LC & 1,2 & $<0,1$ & $<0,1$ & & & \\
\hline Locustella fluviatilis & 2 & $\mathrm{PH}$ & C4 & & - & - & - & & & \\
\hline Locustella luscinioides & 10 & $\mathrm{PH}$ & $\mathrm{C} 4$ & LC & 17,7 & 0,1 & 0,5 & $<0,1$ & & \\
\hline Motacilla flava & 7 & $\mathrm{H}$ & D12 & $\mathrm{LC}$ & 16,5 & $<0,1$ & 0,1 & $<0,1$ & $<0,1$ & \\
\hline Motacilla cinerea & 2 & M & & LC & 8,2 & $<0,1$ & $<0,1$ & $<0,1$ & $<0,1$ & 0,3 \\
\hline Motacilla alba & 20 & Ho & & LC & 36,5 & 0,2 & 0,7 & $<0,1$ & 0,3 & \\
\hline Emberiza schoeniclus & 20 & $\mathrm{H}$ & D14 & LC & 63,5 & 0,5 & 1,6 & $<0,1$ & 0,4 & 5,6 \\
\hline Aix sponsa & 1 & $\mathrm{Ho}$ & & & 4,7 & $<0,1$ & & & $<0,1$ & \\
\hline
\end{tabular}

\section{Diskusia}

Dlhodobé trendy početnosti vtákov na Levických rybníkoch od roku 1953 (cf. Randík 1962) nie sú známe, nakol'ko výskum avifauny sa tu neuskutočňoval kontinuálne.

Zo zástupcov kačíc (Anatidae) v rokoch 1977 - 1987 na Levických rybníkoch hojne hniezdili predovšetkým Aythya ferina a od roku 1980 aj A. fuligula (Zach 1985). Už v tomto období ich početnost' značne fluktuovala s celkovo negatívnym populačným trendom (Zach 1988a), ktorý pokračoval v rokoch 2003 - 2005, kedy už A. fuligula na Levických rybníkoch nehniezdila (Turčoková 2006) a v rokoch 2018 - 2020 sme túto chochlačku kategorizovali ako pravdepodobného hniezdiča (tabul'ka 1). Výrazne sa znížila aj početnost' hniezdnej populácie A. ferina a Anas plathyrhynchos. Negatívny populačný trend druhu $A$. ferina bol zaznamenaný na úrovni celej krajiny (Černecký et al. 2020). Hniezdenie druhu Anas querquedula nebolo od roku 1980 zaznamenané (cf. Zach 1985, 1987).

Turčoková (2006) poukázala na vymiznutie v minulosti hniezdiaceho druhu Podiceps nigricollis (Zach 1985, 1988a, 1990) na lokalite v dôsledku negatívneho populačného trendu v strednej Európe (Cepák 2008). Podobne druhy Chroicocephalus ridibundus (Laridae), Sterna hirundo, Chlidonias niger (Sternidae) a Charadrius dubius (Charadriidae), ktoré na lokalite vzácne zahniezdili v rokoch 1977 1985 v efemerálnych habitatoch pri nízkom stave vodnej hladiny (Zach 1985), neboli do roku 2020 ako hniezdiče vôbec zaznamenané.

$\mathrm{V}$ rámci spevavcov (Passeriformes) ako hniezdič z lokality aktuálne takmer vymizol druh Remiz pendulinus, ktorý tu v rokoch 1977 - 1985 pravidelne a početne hniezdil na hrádzach rybníkov a pozdíž potokov Perec a Teler (Zach 1985). Výrazne sa znížila aj hniezdna populácia Emberiza schoeniclus, čo zodpovedá výsledkom pozorovaní z iných mokradí v okrese Levice, kde tento druh vo vhodných trstinách v hniezdnom období chýbal (cf. Harvančík 2018). Aktuálne (2018 - 2020) evidujeme pokles početnosti aj u ešte $\mathrm{v}$ nedávnej minulosti hojných druhov spevavcov osobitne neviazaných na mokrade ako napríklad Corvus corone, Carduelis carduelis, Carduelis cannabina, Acrocephalus palustris, Emberiza citrinella, či Passer montanus, čo možno aktuálne pozo- 
rovat' aj v širokom okolí chráneného územia. Ide o druhy s globálne negatívnym populačným trendom (https://www.iucnredlist.org)

V porovnaní s 80-tymi rokmi minulého storočia na lokalite $\mathrm{v}$ nedávnej minulosti pribudli nové pravidelne alebo nepravidelne hniezdiace druhy vtákov ako napríklad Netta rufina (Zach 2002, Turčoková 2006), Cygnus olor (Turčoková 2006), Aythya nyroca (V. a R. Slobodník, Birding Slovakia 2008, Rubáčová 2012 in litt.), Anser anser (Jauschová et al. 2019), Porzana parva, Motacilla flava (T. Jauschová, P. Zach, táto práca). $\mathrm{K}$ progresívnym hniezdičom na rybníkoch v súčasnosti patria $C$. olor, $A$. anser a $C$. aeruginosus. Nepotvrdili sme vymiznutie chriaštel'ov Rallus aquaticus a Porzana parva z lokality (cf. Turčoková 2006); v rokoch 2018 - 2020 zistili sme ich výskyt na väčšine napustených rybníkov a zdokumentovali ich hniezdenie pozorovaním vyvedených mlád'at. V porovnaní s minulost'ou Levické rybníky začali častejšie navštevovat' druhy Ardea purpurea (cf. Turčoková 2006), Mergus merganser, Egretta alba a Microcarbo pygmaeus.

Od začiatku výskumu avifauny v 50-tych rokoch minulého storočia sa na Levických rybníkoch zaznamenal výskyt spolu 206 druhov vtákov, z toho 104 druhov vodných a na vodu viazaných (Randík 1962, Drahoš 1968, Zach 1985, 1987, 1988a, 1990, 2002, Turčoková 2006, táto práca).

Ekosozologický význam lokality v rokoch 2018 - 2020 dokumentuje výskyt 33 druhov európskeho významu (21\% všetkých zaznamenaných druhov). Podl'a Červeného zoznamu vtákov Slovenska (Demko et al. 2014) sme tu zistili 33 ohrozených druhov (1 kriticky ohrozený druh, 8 silne ohrozených druhov, 11 zranitel'ných druhov a 13 takmer ohrozených druhov).

\section{Záver}

Chránený areál Levické rybníky predstavuje významný hniezdny biotop a migračnú zastávku vtáctva napriek tesnej blízkosti rušného mesta Levice. Vel'ká plocha litorálnych porastov činí z rybničnej sústavy v intenzívne využívanej agrárnej a industrializovanej nížinnej krajine „hot-spot“" z hl'adiska výskytu vtáctva. Lokalita je v súčasnosti extenzívne rybársky obhospodarovaná, čo optimálne podporuje rozširovanie makrofytnej vegetácie a vytváranie čoraz lepších podmienok na hniezdenie predovšetkým vodného vtáctva. Porasty tvrdých makrofytov v porovnaní s minulost'ou viac štruktúruje diviačia zver, čo podmieňuje vznik otvorených vodných plôch (lagún) a ekotonov prít’ažlivých pre vtáky. Ochrana a zachovanie tejto unikátnej ornitologickej lokality sú nad’alej aktuálne a bez existencie a podpory rybnikárstva sotva možné.

\section{Pod'akovanie}

E. Števková, P. Hoffmann a L. Rubáčová poskytli cenné informácie o výskyte niektorých vzácnych druhoch vtákov na Levických rybníkoch. Pracovníci rybárstva Vel'ká ryba spol. s.r.o. umožnili vstup na Levické rybníky za účelom pozorovania vtáctva.

\section{Literatúra}

Cepák J. 2008: Potápka černokrká (Podiceps nigricollis). - Pp.: 79-81. In: Cepák J., Klvaňa P., Škopek J., Schröpfer L., Jelínek M., HoŘÁk D., Formánek J. \& ZÁrybnickÝ J. (eds.): Atlas migrace ptáků České republiky a Slovenska. - Aventinum, Praha.

Černecký J., Lešo P., Ridzoň J., Krištín A., KARAsKa D., Darolová A., Fulín M., Chavko J., Bohuš M., KrajNiak D., Ďuricová V., Lešová A., Čuláková J., SAXA, A., Durkošová J. \& ANDráš P. 2020. Stav ochrany vtáctva na Slovensku v rokoch 2013 - 2018. - ŠOP SR, Banská Bystrica.

DANko Š. 2006: Zmeny v avifaune rybničnej oblasti Iňačovce-Senné a NPR Senné v rokoch 1995-2004. - Tichodroma 18: 1-30.

Demko M., Krištín A. \& PAČEnovský S. 2014: Červený zoznam vtákov Slovenska. — SOS/BirdLife Slovensko, Bratislava.

Drahoš M. 1968: Vodné vtáctvo na rybníkoch pri Leviciach.-Ochrana fauny 2-3: 15-26.

HARVANČí́ S. 2018: Ornitologické zaujímavosti z okresu Levice. Správa CHKO Ponitrie. http://chkoponitrie. sopsr.sk/ornitologicke-zaujimavosti-z-okresu-levice/ 
JANDA J. \& ŘEPA P. 1986: Metody kvantitativního výzkumu v ornitologii. - Státní zemědělské nakladatelství, Praha.

Jauschová T., Turčoková Rubáčová L. \& Zach P. 2019: Prvé dokázané hniezdenie husi divej (Anser anser) na Levických rybníkoch (juhozápadné Slovensko). Tichodroma 31: 32-36.

Kovalik P., PaČEnovský S., Čapek M.\&Topercer J.2010; Slovenské mená vtákov sveta. — SOS/BirdLife Slovensko, Bratislava.

RANDík A. 1962: Ornitologické poznámky z rybníkov pri Leviciach. - Zborník prác z ochrany prírody v západoslovenskom kraji. Krajské stredisko štátnej pamiatkovej starostlivosti a ochrany prírody: 103-107.

TuRČOKovÁ L. 2006: Vývoj avifauny na Levických rybníkoch za posledných 50 rokov. - Tichodroma 18: 51-55.

TuRČoKová L. \& BALÁž M. 2011: Klimatické podmienky a početnost' fúzatky trstinovej (Panurus biarmicus) v zime na Levických rybníkoch. - Tichodroma 23: 1-6.

ZACH P. 1985: Levické rybníky ako rezervoár vodnej pernatej zveri. — Diplomová práca. VŠLD, Zvolen, 80 pp.

ZACH P. 1987: Niekol'ko poznámok k hniezdeniu kane močiarnej (Circus aeruginosus) pri Leviciach. - Tichodroma 1: 108-110.
ZACH P. 1988a: Aktuálne problémy ochrany vodného vtáctva na území chránenej študijnej plochy Levické rybníky. Zborník z konferencie Vodní ptáci 1987, Přerov, $21-28$.

ZACH P. 1988b: Neskorý výskyt drozda kolohrivca (Turdus torquatus L.) na území chránenej študijnej plochy Levické rybníky. Zprávy MOS, 46, 139-140.

ZACH P. 1990: Changes in breeding bird communities on ponds near Levice in 1977-1988, as exemplified by pond No. 2. - Pp.: 449-452. In: ŠŤASTNÝ K. \& BEJČEK V. (eds.): Bird census and atlas work. Proceeding of the conference, Prague.

ZACH P. 1999: Výskyt kormorána velkého (Phalacrocorax carbo) na rybníkoch pri Leviciach (juhozápadné Slovensko): frekvencia výskytu a početnost' v rokoch 1977 - 1998. - Tichodroma 11: 23-29.

ZACH P. 2002: Prvý doklad o hniezdení hrdzavky potápavej (Netta rufina) na rybníkoch pri Leviciach. - Tichodroma 15: 98-101.

http://uzemia.enviroportal.sk/main/detail/cislo/89

https://www.iucnredlist.org
Došlo: 9. 1. 2021

Prijaté: 31. 1. 2021

Online: 28. 2. 2021 
Príloha 1. Pozorovania zriedkavých druhov vtákov v Chránenom areáli Levické rybníky v období 2018 - 2020.

Appendix 1. Observations on scarce bird species in the Levice fishponds in 2018-2020.

Podiceps auritus. Vel'mi vzácny transmigrant. 28. 5. 2020 bol pozorovaný jeden jedinec vo svadobnom šate (E. Števková). Následne bol pozorovaný aj autormi, poslednýkrát 1. 6. 2020 v kŕdli lysiek na rybníku 3 (TJ, PZ). Prvé pozorovanie druhu na lokalite.

Podiceps nigricollis. V minulosti transmigrant (Randík 1962, Drahoš 1968), v 80-tych rokoch minulého storočia pravidelný hniezdič takmer na každom rybníku (Zach 1985, 1990), v súčasnosti vzácny transmigrant. 24. 5. 2019 bol na lokalite pozorovaný jedinec vo svadobnom šate (S. Harvančík, L. Šnírer, Birding Slovakia) a 26. 5. 2019 pravdepodobne ten istý jedinec na rybníku 2 (TJ).

Microcarbo pygmaeus. V posledných rokoch druh navštevuje lokalitu pravidelne. 21. 4. 2019, 4. 7. 2019, 21. 7. 2019, 11. 7. 2020 sa na lokalite vyskytoval jeden jedinec (TJ). 20. 7. 2020 nocovalo 13 jedincov na rybníku 4 a 20. 8. 2020 strávilo noc na tom istom rybníku 7 jedincov (PZ).

Botaurus stellaris. V minulosti vzácny transmigrant (Drahoš 1968) a možný vzácny hniezdič (Zach 1985). Prelet jedinca pozorovala L. Rubáčová 8. 9. 2009. 28. 9. 2019 bol pozorovaný preletujúci jedinec na rybníku 2 (PZ) a 11. 10. 2020 preletujúci jedinec na rybníku 3 (TJ,Z. Lehká).

Ixobrychus minutus. Hniezdiaci druh v minulosti (Drahoš 1968, Zach 1985). Pozorovania dospelých a mladých jedincov v máji až júli 2018, 2019 a 2020 dokumentujú hniezdenie druhu na lokalite v počte aspoň 5 párov (TJ, PZ).

Ardeola ralloides. Vel'mi vzácny návštevník. 26. 5. 2019 adultný jedinec lovil v potoku Teler a následne preletel na rybníky (obr. 5) (TJ). 29. 5. 2020 subadultný jedinec atakovaný kaňami močiarnymi lietal predpoludním nad porastom makrofytov na rybníku 3. Popoludní odpočíval na pol’ahnutej pálke v západnej časti rybníka 3 (PZ). Prvé pozorovanie druhu na lokalite.

Egretta garzetta. V minulosti (Zach 1985) aj súčasnosti vzácny návštevník lokality. V dňoch 3. 8. 2018, 7. 6. 2019, 15. 8. 2020 (TJ) a 26. 8. 2020 bol na lokalite pozorovaný jeden jedinec (TJ, PZ).

Ardea alba. V minulosti zriedkavý druh (Drahoš 1968, Zach 1985), neskôr častejší a početnejší (Turčoková 2006). V súčasnosti sa vyskytuje celoročne. Početnost' kulminuje po jesennom vypustení rybníkov (TJ, PZ). 31. 10. 2019 sa na rybníkoch zdržiavalo 147 jedincov (TJ).

Ardea purpurea. V minulosti vel'mi vzácny druh (Drahoš 1968, Zach 1985). V súčasnosti sa vyskytuje častejšie, čo naznačuje aj Turčoková (2006). V máji až auguste 2018,
2019 a 2020 sa na lokalite zdržiavali 1 - 2 jedince bez náznakov hniezdenia (TJ, PZ).

Plegadis falcinellus. Vzácny zatúlanec zaznamenaný na lokalite v počte 6 jedincov v roku 1960 (Drahoš 1968). Ráno (8:00) 29. 4. 2020 jeden jedinec hl'adal potravu vo východnej časti napúšt’aného rybníka 2 (PZ). Prvé pozorovanie druhu na lokalite po 60 rokoch.

Cygnus cygnus. Vzácny transmigrant. Dňa 24. 9. 2019 juvenilný jedinec odpočíval na rybníku 2 (TJ). Neskôr 11. 10. 2019 sa subadultný jedinec zdržiaval na tom istom rybníku (PZ).

Anser albifrons. Na lokalite sa vyskytuje predovšetkým v období jesenného t'ahu. Dňa 3. 10. 2020 sa na rybníku 1 zdržiavalo 11 jedincov (TJ, PZ). Jeden jedinec 9. 10. 2020 odpočíval na vypustenom rybníku 2 (PZ).

Anser anser. V minulosti zriedkavý transmigrant (Zach 1985). Na lokalite hniezdi od roku 2017 (Jauschová et al. 2019). V rokoch 2017 a 2018 vyhniezdil jeden pár a v roku 2019 vyhniezdili dva páry (Jauschová et al. 2019). V roku 2020 pät' párov vyviedlo spolu 20 mlád'at (TJ, PZ).

Tadorna tadorna. Vzácny transmigrant. Samec bol pozorovaný 19. 11. 2020 na rybníku 4 (TJ). Prvé pozorovanie druhu na lokalite.

Netta rufina. Druh bol na lokalite prvýkrát zaznamenaný v roku 1982 (Zach 1985). Hniezdi od roku 1997 (Zach 2002). V roku 2003 a 2004 vyhniezdil jeden pár (Turčoková 2006). Ďalšie údaje o hniezdení sú z rokov 2013 a 2017 (L. Turčoková, databáza Aves). V rokoch 2018 a 2019 sa hniezdenie druhu nezistilo (TJ, PZ). Samica s 8 mlád’atami bola pozorovaná 12. 6. 2020 na rybníku 3 (PZ).

Aythya nyroca. Dňa 26. 6. 2008 bola pozorovaná samica so 4 mlád'atami na rybníku 3 (Slobodník R., Slobodník V., Birding Slovakia). Ide o prvý údaj o hniezdení druhu na lokalite. Tri jedince boli pozorované 11. 4. 2012 L. Rubáčovou (in litt.). V hniezdnom období 2019 - 2020 sa jeden pár (obr. 6) zdržiaval na rybníkoch 2 a 3 (TJ, PZ). V mimohniezdnom období sa vyskytuje častejšie, maximálne 4 jedince boli pozorované 3. 10. 2020 (TJ).

Bucephala clangula. V minulosti nehojný transmigrant s t’ažiskom výskytu skoro na jar (Zach 1985). Pozorovania jedného až dvoch jedincov sú z 3. 3. 2019, 31. 10. 2019, 16. 2. 2020 a 20. 2. 2020 (TJ). Dva jedince odpočívali na rybníku 4 23. 11. 2019 (PZ).

Mergellus albellus. Vzácny druh na lokalite v minulosti (Randík 1962, Drahoš 1968) i súčasnosti. Jeden jedinec bol 29. 11. 2019 pozorovaný na rybníku 4 (TJ). 


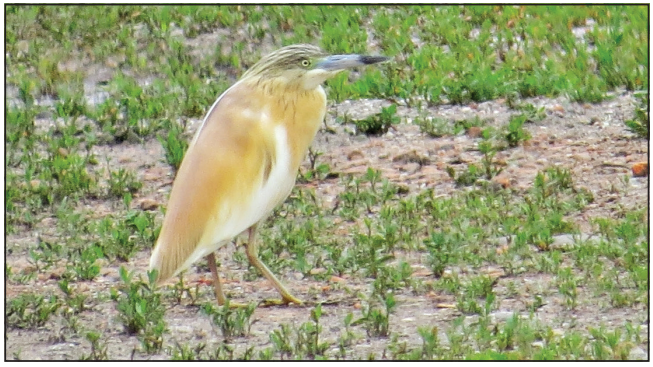

Obr. 5. Dospelý jedinec čapličky vlasatej (Ardeola ralloides) na Levických rybníkoch, 26. 5. 2019 (Foto: T. Jauschová).

Fig. 5. An adult Squacco Heron (Ardeola ralloides) in the Levice fishponds, May 26, 2019 (Photo by T. Jauschová).

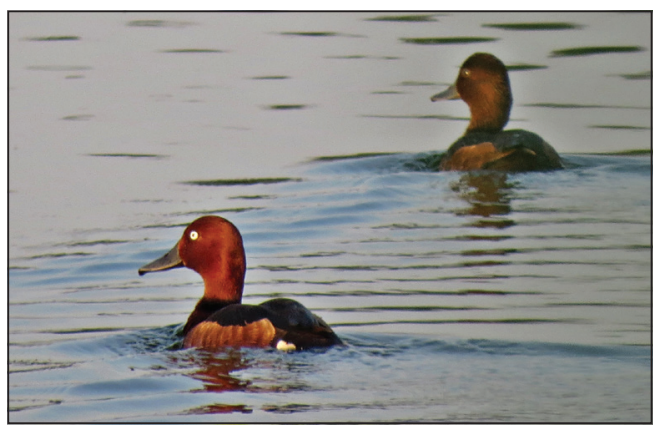

Obr. 6. Pár chochlačiek bielookých (Aythya nyroca) v hniezdnom období na Levických rybníkoch, 7. 6. 2020 (Foto: T. Jauschová).

Fig. 6. A pair of the Ferruginous Duck (Aythya nyroca) in a breeding season in the Levice fishponds, June 7, 2019 (Photo by T. Jauschová).

Mergus merganser. Vzácny zimný host' (Randík 1962, Zach 1985). V súčasnosti je častejší. Jeden pár bol 19. 11. 2019 pozorovaný na rybníku 4 (TJ).

Haliaeetus albicilla. V minulosti zriedkavý host' (Zach 1985). V súčasnosti navštevuje lokalitu častejšie, nakol'ko v širšom okolí hniezdi. V termínoch 17. 10. 2018, 18. 10. 2018, 14. 4. 2019, 25. 8. 2019, 19. 10. 2019 bol pozorovaný 1 jedinec (TJ). V dňoch 2. 8. 2019 a 17. 8. 2019 adultný jedinec odpočíval na odumretých jelšiach východne od rybníka 1 (PZ).

Circus aeruginosus. Druh na lokalite hniezdi od roku 1985 (Zach 1987). V roku 2017 hniezdilo 15 párov a v rokoch 2018 - 2020 tvorilo hniezdnu populáciu 5 - 10 párov (TJ, PZ).

Pandion haliaetus. Zriedkavo zaznamenávaný transmigrant (Drahoš 1968). Jedného jedinca zaznamenala 8. 9. 2008 a 16. 8. 2010 L. Rubáčová (in litt.). Jeden jedinec 22. 9. 2019 prelietal nad rybníkom 6 (PZ) a 13. 9. 2020 jeden jedinec lovil ryby na rybníku 4 (P. Hoffmann).
Rallus aquaticus. V minulosti nehojný druh (Drahoš 1968, Zach 1985). V súčasnosti početne hniezdi a pravidelne zimuje na napustených rybníkoch a pri potoku Teler (cf. Zach 1985). Juvenilný jedinec bol 20. 7. 2020 pozorovaný na rybníku 3 (PZ).

Porzana porzana. Najmenej poznaný chriaštel' na lokalite. Dňa 13. 4. 2019 sa jeden jedinec ukrýval v litorálnej vegetácii v severnej časti rybníka 5 (TJ, PZ).

Porzana parva. Pozornosti unikajúci druh na lokalite zaznamenaný už v roku 1960 (Drahoš 1968) a tiež neskôr (Zach 1985), v rokoch 2003 - 2005 zistený nebol (Turčoková 2006). Koncom apríla a začiatkom mája 2020 sa súčasne ozývalo 6 samcov v litoráli rybníka 4, kde boli 25. 5. 2020 pozorované 3 čerstvo vyliahnuté mlád'atá. Následne 26. 7. 2020 samec vodil jedno mlád’a (obr. 7) a samica z páru vodila 5 mlád'at v prachovom perí na rybníku $3(\mathrm{PZ})$.

Grus grus. Na lokalite vel'mi vzácny transmigrant. Ráno 28. 3. 2020 sa jeden jedinec ozýval z rybníka 4 a neskôr preletel na rybník 3 (PZ). Jeden jedinec 19. 5. 2020 preletoval nízko nad rybníkmi, 20. 5. 2020 dva jedince odpočívali na rybníku 2 a 2. 6. 2020 bol jeden jedinec pozorovaný na rybníku 2 (P. Hoffmann). Prvé pozorovanie druhu na lokalite.

Charadrius hiaticula. Transmigrant $\mathrm{v}$ minulosti (Randík 1962) i súčasnosti. V máji 2020 sa na vypustenom rybníku 1 zdržiavali viaceré jedince asi týždeň, napríklad 21. 5. 2020 až 8 jedincov (TJ).

Pluvialis squatarola. Zriedkavý transmigrant v minulosti (Randík 1962) a pravidelný transmigrant v súčasnosti. V októbri 2019 sa na lokalite tri týždne zdržiavali 2 jedince (TJ). Dňa 9. 10. 2020 jeden jedinec odpočíval na rybníku 3 (TJ, PZ).

Calidris alpina. Transmigrant v minulosti (Randík 1962, Drahoš 1968) i súčasnosti. Spolu 66 jedincov 15. 10. 2020 odpočívalo a hl'adalo si potravu na rybníku 2 (TJ).

Lymnocryptes minimus. V minulosti tento nenápadný druh pravidelne zimoval na Čertovom potoku juhovýchodne od rybníkov (PZ, nepublikované údaje z rokov 1980 1985). Jeden jedinec 28. 3. 2020 celý deň odpočíval a hl'adal potravu v lagúne rybníka 3 na okraji porastu makrofytov v spoločnosti piatich jedincov Tringa ochropus (PZ). Prvé pozorovanie druhu na lokalite.

Tringa erythropus. Vzácny transmigrant. Dňa 3. 5.2020 sa 8 jedincov zdržiavalo na rybníku 2 (PZ). Výskyt druhu na lokalite priaznivo ovplyvnilo neskoré napúšt'anie rybníka. Prvé pozorovanie druhu na lokalite.

Tringa totanus. Vzácny transmigrant v minulosti (Randík 1962, Drahoš 1968) i súčasnosti. Dva jedince 29. 4. 2020 odpočívali a hl'adali potravu na neskoro napúšt’anom rybníku 2 (PZ). 


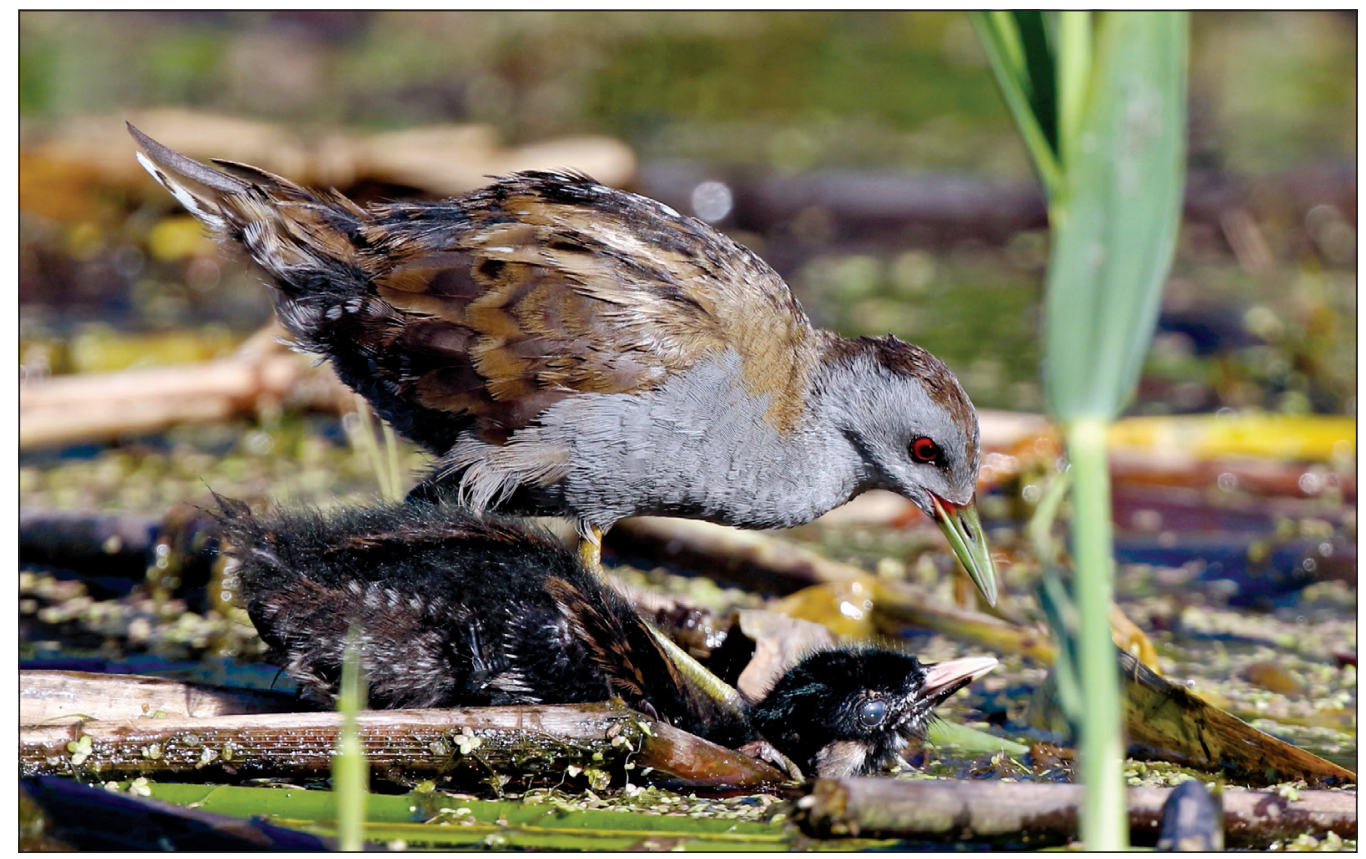

Obr. 7. Chriašt' malý (Porzana parva): samec vodiaci mlád’a. Levické rybníky, 27.7.2020 (Foto: P. Zach).

Fig. 7. The Little Crake (Porzana parva): a male with a young bird. Levice fishponds, July 27, 2020 (Photo by P. Zach).

Ichthyaetus melanocephalus. Zriedkavý transmigrant. Jeden jedinec bol pozorovaný 23. 3. 2019 v kŕdli 15 jedincov Chroicocephalus ridibundus na rybníku 4 (PZ). Prvé pozorovanie druhu na lokalite.

Hydroprogne caspia. Vzácny transmigrant. Jeden jedinec bol 28. 4. 2019 pozorovaný pri prelete nad rybníkom 4 (TJ, PZ). Prvé pozorovanie druhu na lokalite.

Sterna hirundo. V minulosti hojný transmigrant, resp. návštevník z hniezdnej kolónie na Hrone (Randík 1962, Drahoš 1968). V súčasnosti zriedkavý transmigrant. V dňoch 17. 8. 2019 a 16. 5. 2020 jeden jedinec lovil na rybníku 1 a 2 (PZ).

Chlidonias hybrida. V minulosti vzácny transmigrant (Zach 1985), v súčasnosti sa pravidelne vyskytuje na jarnom t’ahu jednotlivo alebo v menších skupinách. Maximálny počet 10 jedincov bol zaznamenaný 26. 5. 2019 (TJ).

Chlidonias niger. Transmigrant (Randík 1962, Drahoš 1968), resp. vel'mi vzácny príležitostný hniezdič (Zach 1985). Zo dňa 1. 5. 2010 pochádza záznam o pozorovaní 1 jedinca (L. Rubáčová in litt.). Na rybníkoch 28. 4. 2019 a 8. 5. 2020 lovili 3 jedince, 31. 7. 20195 jedincov a 4. 7. 20202 jedince (TJ).

Panurus biarmicus. Prvý záznam o výskyte druhu na lokalite je z roku 1982 (Zach 1985). Hniezdenie nebolo dokázané (Zach 1985, Turčoková \& Baláž 2011). Na rybníku 4 boli 13. 4. 2019 pozorované 2 páry (TJ, PZ). Dňa 27. 10. 2020 sa 13 jedincov zdržiavalo v porastoch na rybníku 4 (TJ) a 15. 12.2019 asi 20 jedincov na rybníku 3 (PZ). Väčšina jedincov zimujúcich na lokalite pochádza z hniezdnej populácie v Parížskych močiaroch (Turčoková \& Baláž 2011).

Remiz pendulinus. V minulosti bežný a početný hniezdič na lokalite (Zach 1985). V súčasnosti hniezdi nepravidelne a vo vel'mi nízkej početnosti v brehovom poraste potoka Perec, kde boli 2. 7. 2019 pozorované 4 mladé jedince (TJ).

Emberiza schoeniclus. Pravidelne hniezdiaci a zimujúci druh. V minulosti bol ovel'a hojnejší hniezdič ako v súčasnosti. Zníženie početnosti hniezdnej populácie na niekol'ko málo párov, napriek zlepšeniu kvality hniezdneho biotopu, je alarmujúce a odráža negatívny populačný trend druhu na Slovensku (Černecký et al. 2020).

Aix sponsa. Vzácny návštevník. Od 19. 10. 2018 do 5. 11. 2018 sa jeden samec zdržiaval na rybníku 4 a 5. Dňa 27. 10. 2020 bol jeden samec pozorovaný na potoku Perec (TJ). Prvé pozorovanie druhu na lokalite.

Aquila chrysaetos. Mladý jedinec 8. 3. 2019 preletoval nad rybníkmi smerom na juh (TJ).

Upupa epops. Zriedkavý transmigrant. Jeden jedinec bol pozorovaný 9. 9. 2020 na pol'nej ceste pri rybničnej sústave. Jediný záznam druhu v rokoch 2018 - 2020 (TJ). 
Príloha 2. Prehl'ad ostatných druhov vtákov zaznamenaných v Chránenom areáli Levické rybníky v rokoch 2018 - 2020 a v minulosti (Randík 1962, Drahoš 1968, Zach 1985, Turčoková 2006).

Appendix 2. Survey of other bird species recorded in the in the Protected area Levice fishponds in 2018-2020 and in the past (Randik 1962, Drahoš 1968, Zach 1985, Turčoková 2006).

Phasianus colchicus (H), Accipiter nisus (Ho), Accipiter gentilis (Ho), Buteo buteo (Ho), Buteo lagopus (M), Aquila heliaca (Ho), Aquila chrysaetos (M), Falco tinnunculus (PH), Falco cherrug (M), Falco peregrinus (M), Columba palumbus $(\mathrm{H})$, Streptopelia turtur $(\mathrm{PH})$, Streptopelia decaocto (PH), Cuculus canorus (PH), Apus apus (Ho), Upupa epops (M), Merops apiaster (Ho), Dendrocopos minor $(\mathrm{PH})$, Dendrocopos syriacus $(\mathrm{PH})$, Dendrocopos major $(\mathrm{H})$, Dryocopus martius (PH), Picus viridis (PH), Lanius collurio $(\mathrm{H})$, Lanius excubitor $(\mathrm{Ho})$, Oriolus oriolus $(\mathrm{H})$, Garrulus glandarius $(\mathrm{MH})$, Pica pica $(\mathrm{H})$, Coloeus monedula $(\mathrm{H})$, Corvus frugilegus $(\mathrm{H})$, Corvus cornix $(\mathrm{PH})$, Corvus corax (Ho), Poecile palustris (MH), Parus major (H), Cyanistes caeruleus $(\mathrm{H})$, Alauda arvensis $(\mathrm{PH})$, Hirundo rustica (Ho), Delichon urbicum (Ho), Aegithalos caudatus $(\mathrm{H})$, Phylloscopus trochilus (M), Phylloscopus collybita (PH), Phylloscopus sibilatrix (M), Hippolais icterina (PH), Sylvia atricapilla $(\mathrm{PH})$, Sylvia curruca $(\mathrm{PH})$, Sylvia communis $(\mathrm{MH})$, Regulus regulus (M), Troglodytes troglodytes $(\mathrm{PH})$, Sitta europaea $(\mathrm{H})$, Certhia familiaris $(\mathrm{PH})$, Sturnus vulgaris $(\mathrm{MH})$, Turdus merula $(\mathrm{H})$, Turdus pilaris $(\mathrm{H})$, Turdus philomelos $(\mathrm{H})$, Turdus viscivorus $(\mathrm{M})$, Erithacus rubecula $(\mathrm{PH})$, Luscinia megarhynchos $(\mathrm{PH})$, Phoenicurus ochruros (PH), Saxicola rubetra (M), Saxicola rubicola $(\mathrm{H})$, Muscicapa striata (H), Passer montanus (MH), Prunella modularis (M), Anthus trivialis (M), Fringilla coelebs $(\mathrm{PH})$, Fringilla montifringilla $(\mathrm{M})$, Serinus serinus $(\mathrm{PH})$, Carduelis chloris (PH), Carduelis spinus (M), Carduelis carduelis $(\mathrm{H})$, Carduelis cannabina $(\mathrm{PH})$, Pyrrhula pyrrhula (M), Coccothraustes coccothraustes (MH), Emberiza citrinella (MH), Calidris ferruginea (Randík 1962), Calidris minuta (Randík 1962, Drahoš 1968), Platalea leucorodia
(Drahoš 1968), Mergus serrator (Drahoš 1968), Melanitta fusca (Zach 1985), Limosa limosa (Zach 1985), Limosa lapponica (Zach 1985), Numenius arquata (Zach 1985), Gallinago media (Drahoš in verb. údaj z 1961) Podiceps grisegena (Zach 1985), Anser fabalis (Drahoš 1968, Zach 1985), Aythya marila (Zach 1985), Chlidonias leucopterus (Zach 1985), Larus minutus (Zach 1985), Larus argentatus (Drahoš 1968, Zach 1985), Larus fuscus (Zach 1985, Turčoková 2006), Rissa tridactyla (Zach 1985), Acrocephalus melanopogon (Zach 1985), Aquila pomarina (Zach 1985), Falco subbuteo (Zach 1985), Milvus milvus (Zach 1985), Perdix perdix (Zach 1985), Coturnix coturnix (Zach 1985), Tyto alba (Zach 1985), Athene noctua (Zach 1985), Strix aluco (Zach 1985), Asio otus (Zach 1985), Coracias garrulus (Zach 1985), Jynx torquilla (Zach 1985), Galerida cristata (Zach 1985), Parus ater (Zach 1985), Parus montanus (Zach 1985), Certhia brachydactyla (Zach 1985), Turdus iliacus (Zach 1985), Turdus torquatus (Zach 1985), Oenanthe oenanthe (Zach 1985), Phoenicurus phoenicurus (Zach 1985), Sylvia nisoria (Zach 1985), Sylvia borin (Zach 1985), Ficedula hypoleuca (Zach 1985), Ficedula albicollis (Zach 1985), Anthus spinoletta (Zach 1985), Lanius minor (Zach 1985), Passer domesticus (Zach 1985), Miliaria calandra (Zach 1985), Bombycilla garrulus (Zach 31. 1. 1987), Regulus ignicapillus (Zach 4. 4. 1987), Circus cyaneus (Zach 1985, Turčoková 2006), Circus pygargus (Turčoková 2006).
Došlo: 9. 1. 2021

Prijaté: 31. 1. 2021

Online: 28. 2. 2021 